\title{
The legal reserve: historical basis for the understanding and analysis of this instrument
}

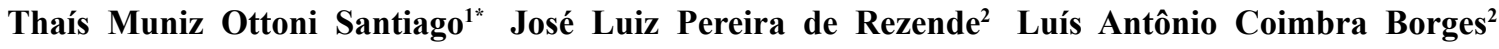

\author{
${ }^{1}$ Programa de Pós-graduação em Engenharia Florestal, Universidade Federal de Lavras (UFLA), 37200-000, Lavras, MG, Brasil. E-mail: \\ thaismottoni@gmail.com. "Corresponding author. \\ ${ }^{2}$ Departamento de Ciências Florestais, Universidade Federal de Lavras (UFLA), Lavras, MG, Brasil.
}

\begin{abstract}
The revisions made in the Forest Code (FC) in 2012 appear to have promoted the weakening of the legal reserve (LR), which after at least 80 years of development, had become established in the Brazilian legal system as an instrument of environmental conservation. This study investigated the possibility of disruption in the implementation of the LR and was developed using qualitative approaches, including bibliographical and documental analyses, to assess the historical construction and legal format of the instrument over time. It was concluded that the current Forest Code broke the trend of development of the $L R$ as an instrument of environmental conservation that was promoted by previous codes and removed the conditions necessary for its effectiveness and existence.

Key words: Brazilian forest code, environmental law, deforestation.
\end{abstract}

A evolução da reserva legal: fundamentos para análise e compreensão do instrumento

RESUMO: Revisões ao Código Florestal feitas em 2012 parecem ter promovido a fragilização da Reserva Legal que, após pelo menos 80 anos de construção, firmou-se no ordenamento jurídico brasileiro como instrumento de conservação ambiental. Este trabalho investigou a hipótese de ruptura do processo de evolução da Reserva Legal. Desenvolveu-se uma pesquisa qualitativa, delineada por métodos bibliográficos e documentais, a qual analisou a construção histórica do instrumento e seu formato jurídico ao longo do tempo. Concluiu-se que o atual Código Florestal Brasileiro rompeu a tendência de construção da Reserva Legal como instrumento de conservação ambiental, promovida pelos códigos anteriores, retirando condições necessárias para sua eficácia e existência.

Palavras-chave: Código florestal brasileiro, legislação ambiental, desmatamento.

\section{INTRODUCTION}

The Legal Reserve (LR) was instituted in Brazil by the Forest Code (FC) in 1934 and has undergone changes to its dimensions and goals over time. The extensive legal framework on which it is based, after intense disputes within the National Congress, succeeded in consolidating it as an instrument of environmental conservation. At present, it establishes the percentage of native vegetation that needs to be maintained in rural properties to guarantee the sustainable economic use of natural resources, assists in the rehabilitation of ecological processes, promotes the biodiversity conservation and protects the native fauna and flora.
Despite its establishment as an instrument of environmental conservation, the LR is still considered to be an area for conversion of forest into pasture or agriculture, as it was in the past. Landowners consider it a barrier against development (CASTRO, 2013); whereas, in the academic sphere, its environmental function is questioned (SIQUEIRA \& NOGUEIRA, 2004), and the instrument is considered responsible for the loss of agricultural output competitiveness (VALVERDE, 2010) and incapable of resisting the pressure of markets (BACHA, 2005). Conversely, it is believed that the weakening of this instrument would lead to irreversible loss of biodiversity (PARDINI et al., 2010), reduction of ecosystem services that favor agricultural production 
(CARVALHEIRO et al., 2011), and undermining of the social achievement that this instrument represents (AHRENS, 2007).

During the review of the FC in 2012, arguments contrary to the establishment of the LR were put forward to justify and claim the reduction of protected areas situated within rural properties. The social context within which such reform occurred seemed to have favored the rupture of the development of LR as an instrument of environmental conservation. Once (1) there was a generalized deficit of areas for which the FC required protection (SPAROVEK et al., 2010); (2) agribusiness was highly valued at the time; (3) pressure exerted by groups and organizations linked to agribusiness influenced the decisions of the National Congress (CUNHA \& MELLO-THERY, 2010).And finally (4) the Ministry of Environment did not have sufficient political clout to protect the natural resources under its guardianship (MENDONÇA, 2012).

The complexity of the new FC and its dependency on the Environmental Rural Register (Cadastro Ambiental Rural [CAR]) and Program for Environmental Regularization (Programa de Regularização Ambiental [PRA]) for the law to take effect has limited the progress of the LR. In addition, the history of non-compliance with the previous FCs and the successive and futile legal obligations of reforesting the LR nourished the questioning about the real intentions of the regulations of the new LR.

Therefore, the purpose of this study was to investigate the possibility of rupture of the development of the LR (as promoted by the current FC) and to discuss the main motivations and implications of the recent changes. The historical construction of the LR is summarized, its legal form over time is analyzed, and its contents and ultimate objectives are explained and justified. This exploratory study used documental and bibliographical methods, contemplated the laws on the topic, and analyzed the different perspectives reported in the literature to provide a basis for understanding the instrument and facilitating the formulation of future research hypotheses.

\section{The legal reserve in the forest code of 1934}

The first Brazilian FC appeared in 1934 as an attempt by the government to control strategic sectors of the economy, allowing and supporting the industrialization of Brazil. To regulate the process of deforestation and ensure the stability of the timber markets, this FC required that $25 \%$ of the area of rural properties contain native vegetation cover and these properties had to be situated at the discretion of the competent authority, although specific rules on the use of such reserves were not created (BRASIL, 1934).

The economic nature of this measure was evident, considering that (1) neither the species nor the variety of trees to be reserved were relevant, and the sole concern was timber production; (2) the idea of a forest reserve suggested allusion to an economic concept in terms of which resources were safeguarded for future use; (3) the properties located close to the forests were exempted from the requirement of containing native vegetation in as much as they already possessed disposable raw materials; and (4) the requirement for the maintenance of reserves was waived in cases in which the landowners intended to remove all of the existing heterogenous vegetation to transform the land into forested plantations.

The 1934 FC was not clear about the possibility of including the amount of forest that should be preserved within the rural property to ensure compliance with the water regime and avoid erosion (protective woodlands) in the calculation of the $25 \%$ rule for the properties that should be kept forested. However, it is evident that the law treated these two regulations differently. In contrast to the native area, which could be completely replaced to facilitate industrial exploitation, the protective woodlands, which were areas of permanent preservation, could only be exploited exceptionally. That is, only in cases in which there was a significant advantage to the Treasury and only after an authorization was granted by the Ministry of Agriculture.

The forest reserves controlled the use of natural resources over time, avoided the irrational exploitation of the forest wealth, and promoted environmental conservation. However, the difficulties in effectively executing the 1934 FC, especially because of the inertia or even resistance of the state and municipal authorities, led to the preparation of a new FC aimed to reorganize and improve the instrument (AHRENS, 2007).

\section{The legal reserve in the forest code of 1965}

The 1965 FC had to comply with the new legal framework, which restricted the use of private property and required the conservation of natural resources to guarantee the well-being of the population (BRASIL, 1964). As such, its protective character was extended, and the Areas of Permanent Preservation (APP) were created, incorporating not only the protective woodlands but also other types of vegetation the location and importance of which 
demanded protection. The percentage of forest reserves varied between the rural properties situated in the north and northern-midwest regions of Brazil $(50 \%)$ and the remaining regions of the country $(20 \%)$, with the exception of rural properties situated in the northeast regions, for which an explicit forest reserve requirement was not available (BRASIL, 1965). The absence of legislation delayed the adoption of the instrument in the latter region and helped explain why only a small area of land had been instituted as LR until date (BACHA, 2005).

As was the case with the previous FC, the competent authority established the location of the forest reserves on a property. Furthermore, the requirement that properties situated close to forested areas have forest reserves was no longer considered to be a reason for exemption, and the inclusion of the APP in the calculation of the percentage of forest reserve became explicitly prohibited. Conversely, the FC of 1965 indicated that rural properties situated outside the Amazonian region and with an area between 20 and 50 hectares should contain forest covers of any nature, taking into account any vegetation containing fruit, ornamental, or industrial trees. Such flexibility suggested that properties of up to 20 hectares situated in this area were not required to have forest reserves. Furthermore, the buyers could group the areas used for completing the forest reserves of such properties in a single plot, or parcel, of land.

The 1965 FC established that the exploration of native vegetation not considered areas of permanent preservation, including forest reserves, depending on a regulation created by federal or state law. However, the tardy regulation and application of this regulation (BRASIL, 2006) might have limited the effectiveness of possible control over the remaining forested areas of Brazil. This FC focused on relaxing the requirements of the forest reserves to small producers and tightening the requirements in regions of interest to maintain a certain degree of equilibrium in the landscape. However, positive incentives were not provided for the maintenance of forest reserves that could have stimulated compliance with the law. Instead, the FC continued to allow producers to remove these reserves, eliminating all native vegetation and replacing it with forest plantations. Therefore, the predominance of the economic nature of these reserves still was evident, and after the supply and stability of the timber market had been assured, they were considered dispensable.

On the basis of the National Environmental Policy (Federal Law n. 6.938 of 1981) and the Federal Constitution of 1988 , a new national public policy guideline was developed in which the environment was recognized as an integrated ecological system that was necessary to ensure the well-being of the population, national security, and sustainability of economic development at the national level. As such, the forest reserves of the $1965 \mathrm{FC}$ assumed new functions, including the supply of raw materials and the provision of environmental services to both rural properties and society in general.

To tailor the legal corpus of the forest reserves to their new functions, Federal Law n.11.284 of 1986 outlawed the shallow cutting of heterogeneous forests for the purpose of replacing them with plantations, and it made forest exploitation dependent on sustainable management and the replacement of forested areas with native species (BRASIL, 1986). Federal law n.7.803 of 1989 contributed to this process by requesting the maintenance of reserves in forest biomes and areas of savannah $(20 \%$ of the rural property), coining the term "legal reserve" and requiring rural property owners to register any LR at the land registry office. This prohibited alterations in the use of these LRs, even in cases of sale or transfer of properties (BRASIL, 1989). By defining the location of LRs within rural properties, this law not only interrupted the practice of successive sales, which led to the complete disappearance of these reserves (BACHA, 2005), but also facilitated the supervision and stability necessary for adequate environmental control.

At the beginning of the 1990s, as the agricultural frontiers reached the limits of the protected APPs and LRs (SIQUEIRA \& NOGUEIRA, 2004), the FC gave signs that, in isolation would be incapable of having a sufficient impact on the use of soil. Consequently, it evidenced the presence of deficits in areas that should have been protected within rural properties (BACHA, 2005). The Agricultural Policy Law (Federal Law n.8.171/1991) established requirements for the regularization of LR deficits in rural properties. At that time, property owners were granted 30 years to fully regularize their LRs (BRASIL, 1991).

The Legal Reserve in provisional measure n. 2166-67 of 2001

Tropical forests were at the heart of the emerging environmental debate. For this reason, deforestation resulting from the tax incentives that promoted the occupation of the Brazilian Amazon damaged the country's image and restricted access to international credit markets. To resolve this matter, provisional measure n.1.511/96 increased 
the LR percentage in properties situated in the Amazon forests from $50 \%$ to $80 \%$ (BRASIL, 1996). Therefore, the LR was the instrument utilized to change the pattern of soil usage in the region and avoid new forest conversions. However, considering that the existing models of exploitation were based on forest conversion, that no alternatives were proposed, and that the region's complex social relations were not considered, the increase in LR, in isolation, did not prevent an increase in the deforestation of the Brazilian Amazon (SIQUEIRA \& NOGUEIRA, 2004; IPEA, 2011; STICKLER et al., 2013).

Alterations to the LR in the Amazon and the institution of sanctions via federal decree n.3.179/1999 against owners who performed shallow cutting of the native vegetation in LR (BRASIL, 1999) triggered a strong reaction from the agribusiness sector. Conflicts occurred between conservationists and productivists and generated 67 re-editions of the provisional measure of 1996, which became law under the provisional measure number $2.166-67$ of 2001. At the end of this process, the concept of LR was redefined, and its conservationist nature was consolidated (BRASIL, 2001).

Property owners in Legal Amazon were required to maintain the following LR levels in accordance to the predominant vegetation profile of the property: $80 \%$ in cases of forests, $35 \%$ in cases of savannah, $20 \%$ in cases of fields, and $20 \%$ in other regions of the country. The inclusion of the APP in the calculation of the LR would be allowed whenever the sum of such areas exceeded (1) $80 \%$ of the property in Legal Amazon, (2) $50 \%$ of areas situated in other regions of the country, and (3) $25 \%$ of small properties, defined according to the type of economic activity, income, and property area. The notarial registration of the LRs was granted free of charge, and cultivation of exotic species was allowed using the intercropping system or in combination with native species.

To overcome the precarious connectivity between the forest fragments, the new FC expanded the possibility of instituting the LR on a shared basis in all Brazilian regions and required that its location considered the proximity to other protected areas. At that time, the LR changed its role from an instrument that sought to ensure the availability of forest raw materials to an instrument that ensured the provision of ecosystem services and the deforestation containment. This was because the twenty-first century demanded or no longer involved the supply of forest markets (plantations subsidized by federal subventions in the 1960s used to support the development of the paper/ pulp and iron/steel industries [TOMASELLI, 2013]). Rather, it involved the decrease of deforestation rates to provide environmental benefits and satisfy the national and international public opinion (SIQUEIRA \& NOGUEIRA, 2004).

The property owners who did not comply with the LR requirements had the option to restore deforested areas via (1) natural regeneration; (2) plantation of native species and use of exotic species as pioneers within a maximum period of 30 years; and (3) compensation for the absence of LRs via acquisition of forested areas in other properties or Units of Conservation (UC) situated within the same ecosystem or, at least, in the same hydrographic basin, providing that it was located in the same state of the area being compensated. Regarding the restoration process, the FC allowed the executive authority to reduce the percentage of LR from $80 \%$ to $50 \%$ of the area of the properties situated in Legal Amazon. This provided that this reduction complied with agricultural and economic-ecological zoning (EEZ) and was approved by the National Council of the Environment, the Ministry of the Environment, and the Ministry of Agriculture. Hence, the FC required the total recovery of the deforested LRs without compromising the ecological functions and the force of the law.

\section{The forest code of 2012}

The increase in the rates of deforestation in the Amazon at the beginning of the twenty-first century (INPE, 2011) triggered efforts to strength the FC effectiveness. One of the measures implemented was Federal Decree n.6.514/2008, which revoked the previous decree and increased the severity of the fines applied to those who did not comply with APP and LR requirements (BRASIL, 2008). These measures displeased the rural sector that combined with future reductions in the deforestation rate in the Amazon and the high value of agribusiness, resulted in a revision of the $\mathrm{FC}$, which was enacted by Federal Law n.12.651 of 2012 (BRASIL, 2012).

The FC of 2012 was prepared on the basis of consensus that the previous versions had little impact on land use, as evidenced by the large native vegetation deficits in areas that should have been protected (SPAROVECK et al., 2010). A solution is necessary for those areas that did not comply with the law and avoid new environmental liabilities. Therefore, the FC of 2012 preserved the conservation requirements of the LRs (with permission to reduce the LRs to $50 \%$ in Legal Amazon states with EEZ approval and those where more than $65 \%$ of the territory was occupied by UCs and adopted new measures aimed to increase 
law compliance. This included (1) CAR, (2) restoration reduction requirements for protected areas, and (3) the Environmental Reserve Quota (Cota de Reserva Ambiental [CRA]).

The CAR is an obligatory electronic registration system that integrates the geo-referenced information of all the rural properties in Brazil. The CAR data includes the location and demarcation of the protected areas, and registration with the CAR waives notarial registration, allowing all producers to qualify for the inclusion of the APP in the LR calculation. This benefit does not imply the conversion of new forested areas and that the area to be included is conserved or in the process of being restored. Moreover, the FC provided that, from 2017 onwards, all rural property owners will have access to rural credit only in cases in which their data are included in the CAR.

After registration, property owners may join the Environmental Regularization Program (Programa de Regularização Ambiental [PRA]) by presenting a simplified proposal including deadlines and conditions for the correction of the environmental deficit. This proposal does not require the contracting of technical personnel. Adherence to the PRA also involves signing a deed to suspend infringements regarding the suppression of the APP and LR before July 22, 2008. Compliance with this deed, in turn, converts such infringements into environmental improvement services. The CAR has the potential to become Brazil's primary strategy for environmental monitoring and planning. However, no deadline has been set for the analysis and validation of the included information by the environmental agency (BRASIL, 2014).

The rural properties with a consolidated anthropic activity and area up to four fiscal modules (FM) on July 22, 2008 were exempt from the obligation to restore the deforested areas in the LR; this included $90 \%$ of the country's rural properties with an area between 20 and 440 hectares. Rural property owners who made deforestations by respecting the LR percentages required for the law at the time of the suppression were also exempt from this requirement. The area to be restored in Brazil decreased by $50 \pm 6$ to $21 \pm 1$ million hectares, of which $78 \%$ contained LRs (SOARES-FILHO et al., 2014). Therefore, the FC opted to reduce the LR requirement to facilitate compliance with the law, even if this meant renouncing the environmental benefits offered by its complete restoration (GARCIA et al., 2013) and contributing to the "culture of cunningness" by devaluing the property owners who had respected the relevant legal requirements (BRANCALION et al., 2016).
The LR deficit in medium-sized and large properties can be corrected via (1) natural regeneration; (2) restoration concluded within 20 years, including the use of exotic species in up to $50 \%$ of the area to be restored; or (3) compensation. The compensation mechanism was extended in the 2012 FC with the creation of the CRA, which replaced the Forestry Reserve Quota of the previous code that did not produce significant effects. The current system promised a viable alternative regarding $\mathrm{FC}$ compliance while offers positive conservation incentives.

The reformulation of this mechanism sought to increase the supply of LRs to the CRA market and expanded the geographical divisions that guided the compensation system, allowing exchanges in the same biome and even between different states. Even though this reformulation brings economic benefits, it may also imply greater environmental costs in cases in which there is not an environmental equivalence between the forest quota exchanges (SILVA \& RANIERI, 2014). The possibility of instituting the CRA was also extended for the purpose of increasing the supply of LRs; quotas can be instituted not only for the intact native vegetation - or in restoration process - that exceed the FC requirements but also can correspond to the total vegetation of small rural properties or of those situated in the UCs. The supply will also increase when the calculation of the APP is sufficient to satisfy the LR percentage, and the remaining native vegetation within any property that cannot be converted will become CRAs.

The inclusion of the APP in the calculation of LRs also reduced the demand for the CRA. The demand also decreased because of the pardon of the deficit of the LR granted to small properties (moved from the category of debtors to creditors). The imbalance between supply and demand for the CRA represented the largest obstacle to the consolidation of this market (SPAROVEK et al., 2012; MAY et al., 2016). The absence of a CRA market and of other measures capable of promoting payment for environmental services may lead to the illegal deforestation of the remaining areas, for which conservation incentives may not be available.

Tables 1 and 2 summarized the development of LR and indicated that the 2012 FC, although maintaining the LR concept, did break the pattern of its development as an instrument of environmental conservation. To facilitate the regularization of rural properties, the $\mathrm{FC}$ removed the conditions necessary to maintain the existence 
Table 1 - Legal reserve evolution within the Brazilian legal framework.

\begin{tabular}{|c|c|c|c|c|c|c|}
\hline \multirow{2}{*}{\multicolumn{2}{|c|}{ Characteristics }} & & & rear & & \\
\hline & & 1934 & 1965 & 1989 & 2001 & 2012 \\
\hline \multicolumn{2}{|l|}{ Designation } & "forestry reserve" & "forestry reserve" & legal reserve & legal reserve & legal reserve \\
\hline \multicolumn{2}{|l|}{ Composition } & - & native & native & native & native \\
\hline \multicolumn{2}{|c|}{$\begin{array}{l}\text { Parameters (according to } \\
\text { location of the farm and } \\
\text { the vegetation ) }\end{array}$} & $25 \%$ & $\begin{array}{l}\text { North and northern } \\
\text { central west }(50 \%) \text {; } \\
\text { Others }(20 \%)\end{array}$ & $\begin{array}{l}\text { North and } \\
\text { northern central } \\
\text { west }(50 \% \mathrm{~F} \text {, } \\
20 \% \mathrm{~S}) \text { Others } \\
(20 \%)\end{array}$ & $\begin{array}{l}\text { LA: }(80 \% \mathrm{~F}, 35 \% \\
\mathrm{S}, 20 \% \mathrm{Fi}) \\
\text { Others }(20 \%)\end{array}$ & $\begin{array}{l}\text { LA: }(80-50 \% \mathrm{~F} \text {, } \\
35 \% \mathrm{~S} 20 \% \mathrm{Fi}) \\
\text { Others }(20 \%)\end{array}$ \\
\hline \multicolumn{2}{|c|}{ APP Computation } & - & no & no & $\begin{array}{l}\mathrm{APP}+\mathrm{LR}=\text { if } \\
80 \% \mathrm{LA}, 50 \% \text { for } \\
\text { rest of country, } \\
25 \% \text { for small } \\
\text { lands }\end{array}$ & $\begin{array}{l}\text { No new } \\
\text { conversion; APP } \\
\text { under restoration } \\
\text { and w/ register in } \\
\text { CAR }\end{array}$ \\
\hline \multicolumn{2}{|l|}{ Declaration } & - & - & Notarial office & Notarial office & CAR \\
\hline \multicolumn{2}{|l|}{ Use } & $\begin{array}{l}\text { Clear-cutting } \\
\text { prohibited }\end{array}$ & Only if authorized & $\begin{array}{l}\text { Only if } \\
\text { authorized }\end{array}$ & SFM & $\begin{array}{l}\text { MFS w/ or w/o } \\
\text { commercial } \\
\text { purposes }\end{array}$ \\
\hline \multicolumn{2}{|c|}{ Condominium } & - & except LA & except LA & yes & yes \\
\hline \multirow{5}{*}{$\begin{array}{l}\text { Distinction } \\
\text { relating to } \\
\text { small } \\
\text { properties }\end{array}$} & Concept & $\begin{array}{l}\text { Small properties } \\
\text { close to forests, at } \\
\text { the option of the } \\
\text { forestry agency }\end{array}$ & $\begin{array}{l}20-50 \text { ha (in the } \\
\text { southeast, southern } \\
\text { central west, and } \\
\text { south) Up to } 20 \mathrm{ha}^{2} \\
\text { seem to be exempt }\end{array}$ & $\begin{array}{l}20-50 \text { ha (in the } \\
\text { southeast, } \\
\text { southern central } \\
\text { west, and south) } \\
\text { Up to } 20 \text { ha }^{2} \\
\text { seem to be } \\
\text { exempt }\end{array}$ & $\begin{array}{l}\text { Family farms, } \\
80 \% \text { of income } \\
\text { from agro- } \\
\text { forestry, max. } \\
\text { area: } 150 \text { ha LA; } \\
50 \text { ha DP; } 30 \text { ha } \\
\text { remain }\end{array}$ & $\begin{array}{l}\text { Family farms, } \% \\
\text { of income defined } \\
\text { by Executive } \\
\text { Authority (Law } \\
11326 / 06 \text { ) + } \\
\text { Properties up to } 4 \\
\text { FM }\end{array}$ \\
\hline & LR & no & $\operatorname{yes}^{1} / \mathrm{no}^{2}$ & yes $^{1} /$ no $^{2}$ & yes & yes \\
\hline & Contents & - & $\begin{array}{l}\text { exotic species } \\
\text { permitted }\end{array}$ & $\begin{array}{l}\text { exotic species } \\
\text { permitted }\end{array}$ & exotic + native & $\begin{array}{l}\text { exotic species } \\
\text { permitted }\end{array}$ \\
\hline & Land use & - & $\operatorname{sim}$ & $\operatorname{sim}$ & MFS & $\begin{array}{l}\text { MFS w/ or w/o } \\
\text { commercial } \\
\text { purposes }\end{array}$ \\
\hline & $\begin{array}{l}\text { LR with } \\
\text { quota }\end{array}$ & - & - & - & - & Yes \\
\hline
\end{tabular}

Notes: $\mathrm{LR}=$ legal reserve; $\mathrm{F}=$ forests; $\mathrm{S}=$ savannah; $\mathrm{LA}=$ Legal Amazon; Fi = fields; $\mathrm{SFM}=$ sustainable forestry management; $\mathrm{DP}=$ drought polygon; $\mathrm{FM}=$ fiscal modules; $\mathrm{CAR}=$ Environmental Rural Register.

and effectiveness of this instrument. For some, the 2012 FC ignored the ecological (METZGER, 2010), legal (AHRENS, 2007), and historical (CASTRO, 2013) pillars that had justified the creation of LRs up to the present time. For others, the weakening, if not disappearance, of the concept of LR would be the best strategy to correct the limitations of a law that, without having considered the social realities, imposed an onerous instrument that impedes agrarian development (VALVERDE, 2010).

The 2012 Forest Code attained the objective of correcting Brazil's environmental debt; however, it still runs the risk of having little impact on land use. Although, it has included new measures to promote compliance with the law, the success of the FC in preventing the formation of new liabilities still depends on the strengthening of the environmental agencies whose current technical and resource deficiencies delay the validation of the information included in the CAR and the monitoring of the evolution of Brazil's vegetation cover. The 2012 FC could have used political strategies that overcame the digital platform of CAR and incentivized environmental conservation at the local level, including programs for rural extension and payment for environmental services (the latter was timidly provided by the $\mathrm{FC}$ but still is required a thorough regulation [BRANCALION et al., 2016]). Such measures are essential and can avoid that the CAR becomes just a passport for credit access and forgiveness for illegal actions (AZEVEDO et al., 2014), and it is able to effectively manage environmental restoration and contribute to the reduction of deforestation.

Ciência Rural, v.47, n.2, 2017. 
Table 2 - Historical record of the regularization of the legal reserve.

\begin{tabular}{|c|c|c|c|c|}
\hline \multicolumn{2}{|l|}{ LR Regularization } & 1991 (Law 8.171) & 2001 (MP 2166-67) & 2012 (Law 12.651) \\
\hline \multicolumn{2}{|c|}{ Regularization Requirement } & yes & yes & $\begin{array}{l}\text { those who abolished in compliance with } \\
\text { the law at the time it were exempted }\end{array}$ \\
\hline \multicolumn{2}{|c|}{ Natural Restoration } & - & yes & Yes \\
\hline \multirow[b]{2}{*}{ Restoration } & Deadline (years) & 30 & 30 & 20 \\
\hline & Composition & $\begin{array}{l}\text { norms of the } \\
\text { managing agency }\end{array}$ & exotic species as pioneers & $\begin{array}{l}\text { exotic species in up to } 50 \% \text { of the } \\
\text { restored area }\end{array}$ \\
\hline \multirow{2}{*}{ Compensation } & Location & 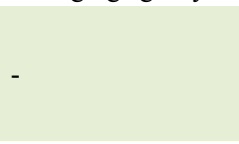 & $\begin{array}{l}\text { Same ecosystem and at } \\
\text { least the same } \\
\text { hydrographic basin within } \\
\text { the same state }\end{array}$ & same biome, preferably within same state \\
\hline & Means & - & $\begin{array}{l}\text { CRF acquisition, area } \\
\text { leased under forestry } \\
\text { servitude, donation of units } \\
\text { of conservation }\end{array}$ & $\begin{array}{l}\text { CRA acquisition, leasing of the area } \\
\text { under forestry servitude, donation of } \\
\text { units of conservation }\end{array}$ \\
\hline \multicolumn{2}{|l|}{ Small Properties } & total restoration & Total restoration & $\begin{array}{l}\text { If a rural consolidated area: LR existent } \\
\text { on July } 22,2008 \text { (exempt) }\end{array}$ \\
\hline \multicolumn{2}{|l|}{ Financial Support } & no & no & $\begin{array}{l}\text { Deduction of income tax from the } \\
\text { expenses incurred, use of public funds for } \\
\text { the granting of loans, exemption of taxes } \\
\text { for the main inputs and equipment used }\end{array}$ \\
\hline \multicolumn{2}{|l|}{ Fines } & should be paid & should be paid & $\begin{array}{l}\text { will be converted into environmental } \\
\text { protection services }\end{array}$ \\
\hline
\end{tabular}

$\mathrm{CRF}=$ Forest Reserve Quota; CRA = Environmental Reserve Quota.

\section{CONCLUSION}

The objectives and regulatory mechanisms of the LR have undergone changes over time. These regulations were initially of an economic nature, with the goal of ensuring the availability of raw materials and the stability of the timber market, and evolved into a conservationist nature in defense of the environmental services. However, the 2012 FC broke the tendency of establishing an instrument of environmental conservation by reducing the requirements for the restoration of environmental liabilities, increasing the use of exotic species, and allowing the indiscriminate overlapping of the APP and LR.

Historically, the FC had little impact on the use of land, and the reviews that sought to increase its effectiveness over time focused predominantly on adjustments of conservation and restoration parameters rather than on the adoption of effective measures aiming to incentivize $i$ and support the producers to create areas of preservation. This aim was not achieved when the conceptualization and objectives of the LR were reformulated, as would have been expected. The 2012 FC innovated by adopting new instruments such as the CAR and the CRA market; nonetheless, it has not been possible to confirm that these instruments will indeed prevent the formation of new environmental liabilities because they still depend on regulation, institutional support, and local actions for the production of the desired effects.

\section{REFERENCES}

AHRENS, S. Sobre a reserva florestal: origens históricas e fundamentos técnico-conceituais. In: CONGRESSO BRASILEIRO DE DIREITO AMBIENTAL, MEIO AMBIENTE E ACESSO À JUSTIÇA: FLORA, LR e APP, 11., 2007, São Paulo, SP. Anais... São Paulo: Planeta Verde, 2007. p.691-707. Online. Available from: <http:/www.planetaverde.org/arquivos/biblioteca/ arquivo_20140212142900_2726.pdf>.Accessed: Sep. 27, 2016.

AZEVEDO, A.A. et al. Cadastro ambiental rural e sua influência na dinâmica do desmatamento na Amazônia Legal. Brasília: Instituto de Pesquisa Ambiental da Amazônia, 2014, 16p. Boletim Amazônia, n.3. Available from: <http://ipam.org. br/wp-content/uploads/2016/04/amaz\%C3\%B4nia_em_pauta_3_ cadastro_ambiental_r.pdf $>$. Accessed: Sep. 27, $201 \overline{6}$.

BACHA, C.J.C. Eficácia da política de reserva legal no Brasil. Teoria e Evidência Econômica, v.13, n.25, p.9-27, 2005. Available from: <http://www.sober.org.br/palestra/12/06O368. pdf $>$. Accessed: Sep. 28, 2016.

BRANCALION, P.H.S. et al. A critical analysis of the Native Vegetation Protection Law of Brazil (2012): updates and ongoing initiatives. Natureza \& Conservação, v.14, p.1-15, 2016. Available from: <http://dx.doi.org/10.1016/j.ncon.2016.03.003>. Accessed: Sep. 27, 2016. doi: 10.1016/j.ncon.2016.03.003.

Ciência Rural, v.47, n.2, 2017. 
BRASIL. Decreto n. 23.793, de 23 de janeiro de 1934. Decreta o Código Florestal. Brasília, DF, 1934. Available from: <http:// www.planalto.gov.br/ccivil_03/decreto/1930-1949/D23793.htm>. Accessed: July 31, 2014.

BRASIL. Decreto n. 3.179, de 21 de Setembro de 1999. Dispõe sobre a especificação das sanções aplicáveis às condutas e atividades lesivas ao meio ambiente, e dá outras providências. Brasília, DF, 1999. Available from: <http://www.planalto.gov.br/ ccivil_03/decreto/D3179.htm>. Accessed: July 25, 2016.

BRASIL. Decreto n. 5.975, de 30 de Novembro de 2006. Regulamenta os arts. 12, parte final, 15, 16, 19, 20 e 21 da Lei no 4.771, de 15 de setembro de 1965, o art. 4o, inciso III, da Lei no 6.938 , de 31 de agosto de 1981 , o art. 2o da Lei no 10.650 , de 16 de abril de 2003, altera e acrescenta dispositivos aos Decretos nos 3.179 , de 21 de setembro de 1999 , e 3.420 , de 20 de abril de 2000. Available from: <http://www.planalto.gov.br/ccivil 03/ Ato20042006/2006/Decreto/D5975.htm>. Accessed: July 30, 2014

BRASIL. Decreto n. 6.514, de 22 de julho 2008. Dispõe sobre as infrações e sanções administrativas ao meio ambiente, estabelece o processo administrativo federal para apuração destas infrações, e dá outras providências. Brasília, DF, 2008. Available from: $<\mathrm{http}: / /$ www.planalto.gov.br/ccivil_03/_ato2007-2010/2008/decreto/ D6514.htm>. Accessed: Aug. 01, 2014.

BRASIL. Lei n. 4.504, de 30 de novembro de 1964. Dispõe sobre o Estatuto da Terra, e dá outras providências. Brasília, DF, 1964. Available from: <http://www.planalto.gov.br/ccivil 03/leis/ 14504.htm>. Accessed: July 31, 2014.

BRASIL. Lei n. 4.771, de 15 de setembro de 1965 . Instituiu o Código Florestal Brasileiro. Brasília, DF, 1965. Available from: $<$ http://www.planalto.gov.br/ccivil 03/leis/14771.htm>. Accessed: Aug 01, 2014.

BRASIL. Lei $n^{\mathbf{0}} \mathbf{7 . 5 1 1}$, de 07 de Julho de 1986. Altera dispositivos da Lei $\mathrm{n}^{\circ} 4.771$, de 15 de setembro de 1965, que institui o novo Código Florestal. Brasília, DF, 1986. Available from: <http://www.planalto.gov.br/ccivil_03/leis/L7511.htm>. Accessed: Aug. 02, 2014

BRASIL. Lei n. 7.803, de 18 julho de 1989. Altera a redação da Lei $\mathrm{n}^{\circ} 4.771$, de 15 de setembro de 1965, e revoga as Leis $\mathrm{n}^{\mathrm{o}} \mathrm{s}$ 6.535, de 15 de junho de 1978, e 7.511, de 7 de julho de 1986 Brasília, DF, 1989. Available from: <http://www.planalto.gov.br/ ccivil 03/leis/17803.htm>. Accessed: Aug. 02, 2014.

BRASIL. Lei n. 8.171, de 17 de janeiro de 1991. Dispõe sobre a política agrícola. Available from: <http://www.planalto.gov.br/ ccivil_03/leis/18171.htm>. Accessed: Aug. 02, 2014.

BRASIL. Lei n. 12.651, de 12 de Maio de 2012. Dispõe sobre a proteção da vegetação nativa; altera as Leis n. 6.938, de 31 de agosto de 1981, 9.393, de 19 de dezembro de 1996, e 11.428, de 22 de dezembro de 2006; revoga as Leis n 4.771, de 15 de setembro de 1965 , e 7.754, de 14 de abril de 1989, e a Medida Provisória $\mathrm{n}^{\circ}$ 2.166-67, de 24 de agosto de 2001. Brasília, DF, 2012. Available from: <http://www.planalto.gov.br/ccivil_03/_ato2011-2014/2012/ lei/112651.htm>. Accessed: Aug. 02, $20 \overline{14}$.

BRASIL. Medida Provisória n. 1.511, de 25 de julho 1996. Dá nova redação ao art. 44 da Lei $n^{\circ} 4.771$, de 15 de setembro de 1965 , e dispõe sobre a proibição do incremento da conversão de áreas florestais em áreas agrícolas na região Norte e na parte Norte da região Centro-Oeste, e dá outras providências. Brasília, DF, 1996. Available from: <http://www.planalto.gov.br/ccivil_03/mpv/ Antigas/1511.htm>. Accessed: Aug. 02, 2014.

BRASIL. Medida Provisória n. 2.166-67, de 24 de agosto de 2001. Altera os arts. $1^{\circ}, 4^{\circ}, 14,16$ e 44 , e acresce dispositivos à Lei n.4.771 de 1965. Brasília, DF, 2001. Available from: <http:// www.planalto.gov.br/ccivil_03/mpv/2166-67.htm>. Accessed: Aug. 02, 2014.

BRASIL. Instrução Normativa n. 2, de 5 de Maio de 2014. Dispõe sobre os procedimentos para a integração, execução e compatibilização do Sistema de Cadastro Ambiental Rural-SICAR e define os procedimentos gerais do Cadastro Ambiental RuralCAR. Available from: <http://www.car.gov.br/leis/IN_CAR.pdf $>$. Accessed: July 01, 2014.

CARVALHEIRO, L.G. et al. Natural and within-farmland biodiversity enhances crop productivity. Ecology letters, v.14, n.3, p.251-259, 2011. Available from: <http://onlinelibrary.wiley.com/ doi/10.1111/j.1461-0248.2010.01579.x/abstract>. Accessed: Sep. 27, 2016. doi: 10.1111/j.1461-0248.2010.01579.x

CASTRO, D.S. A Instituição da reserva legal no código florestal brasileiro: fundamentos histórico-conceituais. Revista do Departamento de Geografia, v.26, p.132-154, 2013. Available from: <http://www.revistas.usp.br/rdg/article/view/75193/78741>. Accessed: July 20, 2014. doi: 10.7154/RDG.2013.0026.0007.

CUNHA, P.R et al. A reserva legal no contexto da política nacional de florestas. In: ENCONTRO NACIONAL DE ANPPAS, 05., 2010, Florianópolis, SC. Anais... Florianópolis, 2010.20p. Available from: <http:/www.anppas.org.br/encontro5/cd/artigos/ GT3-288-210-20100904192616.pdf >. Accessed: Apr. 01, 2014

GARCIA, L.C. et al. Restoration challenges and opportunities for increasing landscape connectivity under the new Brazilian Forest Act. Natureza \& Conservação, v.11, n.2, p.181-185, 2013. Avaiable from: <http://dx.doi.org/10.4322/natcon.2013.028>. Acessed: Sep. 27, 2016. doi: 10.4322/natcon.2013.028

GIL, A.C. Como elaborar projetos de pesquisa. 5.ed. São Paulo: Atlas, 2010. 184p.

INPE. Projeto PRODES: monitoramento da Floresta Amazônica Brasileira por satélite. Guamá Belém (PA), Brasil: National Institute for Space Research (INPE), 2011. Avaiable from: <http:// www.obt.inpe.br/prodes/index.php>. Acessed: Sep. 27, 2016.

IPEA. Código Florestal: Implicações do PL 1876/99 nas Áreas de Reserva Legal. Comunicados IPEA, n.96, 2011, 23p.

MAY, P.H. et al. Environmental reserve quotas in Brazil's new forest legislation: an ex ante appraisal. Bogor, Indonesia: CIFOR, 2015. 38p.

MENDONÇA, R. João Paulo Capobianco: "O governo é pré-histórico na questão ambiental". Revista Época, 13 abr. 2012. Available from: <http://revistaepoca.globo.com/tempo/ noticia/2012/04/joao-paulo-capobianco-o-governo-e-pre-historicona-questao-ambiental-integra.html>. Accessed: June 14, 2014.

METZGER, J.P. O Código Florestal tem base científica? Natureza \& Conservação, v.8, n.1, p.92-99, 2010. Available from: <http:// www.abeco.org.br/node/26>. Accessed: Apr. 02, 2014 doi: $10.4322 /$ natcon. 00801017 . 
PARDINI, R. et al. Beyond the fragmentation threshold hypothesis: regime shifts in biodiversity across fragmented landscapes. Plos One, v.5, n.10, p.e13666, 2010. Available from: <http://dx.doi. org/10.1371/journal.pone.0013666>. Accessed: Sep. 27, 2016. doi: 10.1371/journal.pone.0013666.

SILVA, J.S. et al. O mecanismo de compensação de Reserva Legal e suas implicações econômicas e ambientais. Ambiente \& Sociedade, v.17, n.1, p.115-132, 2014. Available from: <http://www.scielo.br/scielo.php?pid=S1414753X2014000100008\&script=sci arttext $>$. Accessed: Aug. 24, 2014. doi: $10.1590 / 1809-44220005581$.

SIQUEIRA, C.F.A. et al. O Novo Código Florestal e a Reserva Legal: do preservacionismo desumano ao conservacionismo politicamente correto. In: ENCONTRO BRASILEIRO DE ECONOMIA E SOCIOLOGIA RURAL, 24, 2004, Cuiabá, MT. Anais... Cuiabá: Encontro da Sober, 2004. V.24, p.1-20. Available from: <http://sober. org.br/palestra/12/08O387.pdf>. Accessed: Sep. 27, 2016.

SOARES-FILHO, B. et al. Cracking Brazil's forest code. Science, v.344, 363-364, 2014. Available from: $<\mathrm{http}: / /$ science. sciencemag.org/content/344/6182/363>. Accessed: Aug. 23, 2014. doi: $10.1126 /$ science. 1246663 .

SPAROVEK, G. et al. Brazilian agriculture and environmental legislation: status and future challenges. Environmental Science and Technology, v.44, p.6046-6053, 2010. Available from: <http:// pubs.acs.org/doi/abs/10.1021/es1007824>. Accessed: Sep. 27, 2016. doi: $10.1021 / \mathrm{es} 1007824$.

SPAROVEK, G. et al. The revision of the Brazilian Forest Act: increased deforestation or a historic step towards balancing agricultural development and nature conservation? Environmental Science \& Policy, v.16, p.65-72, 2012. Available from: <http://dx.doi.org/10.1016/j. envsci.2011.10.008>. Accessed: Sep. 27, 2016. doi: 10.1016/j. envsci.2011.10.008

STICKLER, C.M. et al. Defending public interests in private lands: compliance, costs and potential environmental consequences of the Brazilian Forest Code in Mato Grosso. Philosophical Transactions of the Royal Society B: Biological Sciences, v.368, n.1619, 2013. Available from: <http://rstb.royalsocietypublishing. org/content/368/1619/20120160>. Accessed: Sep. 27, 2016. doi: 10.1098/rstb.2012.0160

VALVERDE, S.R. O Código Florestal, sua reforma e o setor florestal brasileiro. 2010. Available from: $<$ www.ciflorestas.com. b>. Accessed: July 01, 2014.

TOMASELLI, I. Evolução histórica da indústria florestal brasileira. Revista Referência Florestal, v.XV, n.144, p.3235, 2013. 